УДК 620.92

\title{
ПРОБЛЕМИ ТА ПЕРСПЕКТИВИ РОЗВИТКУ КОГЕНЕРАЦІЇ В УКРАЇНІ
}

\author{
Гелетуха Г.Г., канд. техн. наук, Желєзна Т.А., канд. техн. наук, Баштовий А.І., канд. техн. наук \\ Інститут технічної теплофізики НАН України, вул. Желябова, 2а, Київ, 03680, Україна \\ https:doi.org/10.31472/ttpe.1.2019.8
}

Метою роботи є визначення передумов та перспективних напрямків розвитку високоефективної когенерації в Україні. Проаналізовано законодавчу базу України в сфері когенерації, розроблено пропозиції для іiі покращення 3 урахуванням відповідного досвіду Свросоюзу.
Целью работы является определение предпосылок и перспективных направлений развития высокоэффективной когенерации в Украине. Проанализирована законодательная база Украины в сфере когенерации, разработаны предложения для ее улучшения с учетом соответствующего опыта Евросоюза.
The purpose of the work is to determine the preconditions and perspective lines for the development of high-efficiency cogeneration in Ukraine. The legislative base of Ukraine concerning cogeneration has been analysed, some proposals for its improvement have been developed taking into account the relevant experience of the European Union.

Библ. 15 , табл. 2 , рис. 3 .

Ключові слова: когенерація, високоефективна когенерація, теплоелектроцентраль, теплова електростанція, теплова енергія, електроенергія.

АЕС - атомна електростанція;

ВВП - валовий внутрішній продукт;

ГЕС - гідроелектростанція;

ЗППЕ - загальне постачання первинної енергії;

КГУ - когенераційна установка;

КЕС - кінцеве енергоспоживання;

КМУ - Кабінет Міністрів України;

НКРЕКП - Національна комісія, що здійснює державне регулювання у сферах енергетики та комунальних по-

слуг;

Актуальність роботи обумовлена необхідністю розвитку високоефективного комбінованого виробництва теплової і електричної енергії (когенерації) в Україні як інструменту для скорочення споживання палива і підвищення ефективності виробництва енергії. Метою роботи $\epsilon$ визначення передумов та перспективних напрямків розвитку високоефективної когенерації в країні. Завдання роботи полягають в огляді європейського досвіду в даній сфері, аналізі відповідного українського законодавства, розробці рекомендацій для його вдосконалення. Методи дослідження включають вивчення літературних, статистичних та інших даних, аналіз нормативно-правових актів.

\section{Переваги використання когенерації}

Розвиток комбінованого виробництва теплової i електричної енергії (когенерації) $€$ важливим і актуальним питанням для енергетики України та інших країн. Застосування когенерації дозволяє підвищити загальну ефективність виробництва енергії та заощадити паливно-енергетичні ресурси у порівнянні 3 роздільнім виробництвом. Так, на ТЕЦ коефіцієнт використання палива може бути на 25-30\% вище, ніж при
TEO - техніко-економічне обгрунтування;

TEC - теплова електростанція;

ТЕЦ - теплоелектроцентраль;

ЦТ - централізоване теплопостачання;

н.е. - нафтовий еквівалент.

Нижній індекс:

$\mathrm{e}$ - електричний.

окремому виробництві теплової енергії на котельні та електроенергії на ТЕС (рис. 1).

Для України проблема економії паливно-енергетичних ресурсів і підвищення ефективності їх використання $\epsilon$ вкрай нагальною. Незважаючи на певне зниження протягом останніх $10 \ldots 15$ років первинної та кінцевої енергоємності в Україні, на сьогодні ці показники все ще значно перевищують відповідні величини енергоємності країн $€ С$ (табл. 1).

Розвиток високоефективної когенерації сприятиме зменшенню енергоємності ВВП України і досягненню національної індикативної мети енергозбереження - 9\% середнього показника кінцевого внутрішнього енергоспоживання за період 2005-2009 pp. [1].

\section{Розвиток когенераційних технологій в}

Розвиток когенерації в Євросоюзі вважається важливою складовою енергетичних стратегій і реалізації національних планів країн-членів щодо виконання ï зобов'язань за Кіотським протоколом. За оцінками фахівців Європейської асоціації підтримки когенерації (COGEN Europe), використання когенераційних техно- 

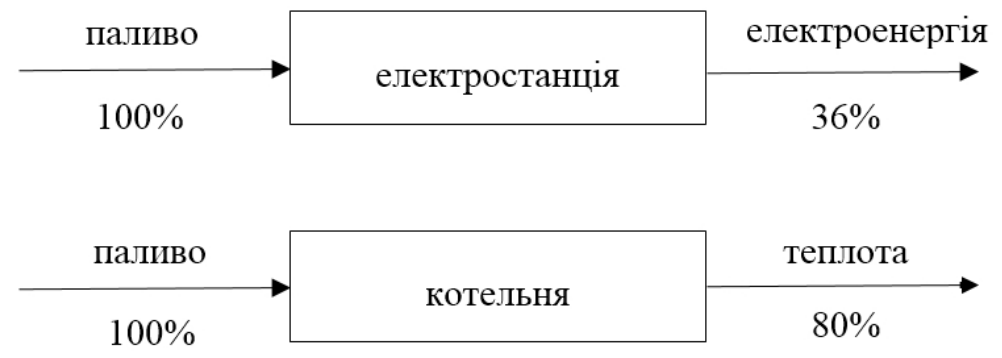

Коефічієнт використання палива $\eta=(36+80) / 200=56 \%$

а) Роздільне виробництво теплової та електричної енергії

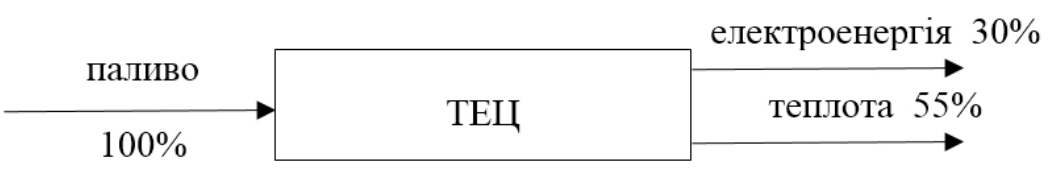

Коефічієнт використання палива $\eta=(30+55) / 100=85 \%$

б) Комбіноване виробництво теплової та електричної енергії

Рис. 1. Порівняння роздільного та комбінованого виробництва теплової і електричної енергї̈.

Табл. 1. Первинна та кінцева енергоємність в Україні та деяких країнах ЄС [1]

\begin{tabular}{|c|c|c|c|c|}
\hline \multirow[t]{2}{*}{ Країни } & \multicolumn{2}{|c|}{$\begin{array}{c}\text { Первинна енергоємність, } \\
\text { ЗППЕ (т н.е.) / ВВП (1000 US\$ 2005 р.) }\end{array}$} & \multicolumn{2}{|c|}{$\begin{array}{c}\text { Кінцева енергоємність, } \\
\text { КЕС (т н.е.) / ВВП (1000 US\$ } 2005 \text { р.) }\end{array}$} \\
\hline & $2002 \mathrm{p}$ & 2012 p. & $2002 \mathrm{p}$. & 2012 p. \\
\hline Україна & 1,98 & 1,28 & 0,78 & 0,77 \\
\hline Литва & 0,44 & 0,25 & 0,24 & 0,20 \\
\hline Польща & 0,33 & 0,24 & 0,21 & 0,16 \\
\hline Швеція & 0,15 & 0,12 & 0,11 & 0,08 \\
\hline Німеччина & 0,12 & 0,10 & 0,09 & 0,07 \\
\hline
\end{tabular}

логій забезпечить виконання близько $15 \%$ загальної цілі ЄС 2020 року по підвищенню енергоефективності і близько 20\% загальної цілі ЄС 2020 року по скороченню викидів парникових газів [2].

На сьогодні в Євросоюзі близько 11\% всієї електроенергії виробляється в режимі когенерації (рис. 2). Лідерами за цим показником є країни СС з високорозвиненою системою централізованого теплопостачання: Словаччина - 80\%, Латвія - 45\%, Данія - 40\%, Фінляндія $-30 \%$, Литва $-30 \%$ (рис. 3). Близько половини теплової енергії, виробленої на ТЕЦ, використовується в ЦТ, решта - у промисловості.

За оцінками COGEN Europe, в СС є потенціал для досягнення 20\% частки ТЕЦ в загальному виробництві електроенергії і 25\% у виробництві тепла (наразі 15\%) до 2030 року. При цьому частка відновлюваних джерел енергії у когенерації може сягнути 33\% (наразі 21\%). За даними 2013 р., встановлена потужність ТЕЦ в СС i Туреччині складає близько 120 ГВт. Поставлено завдання збільшити потужність ТЕЦ в Є С відносно 2010 року на 80\% і довести їі до 180 ГВт у 2050 році [2-4].

У багатьох країнах Євросоюзу діють різні механізми стимулювання розвитку когенераційних технологій (табл. 2). Треба зазначити, що ці механізми є гнучкими, регулярно змінюються і вдосконалюються в залежності від ситуації на ринку і у секторі.

\section{Аналіз законодавчої бази розвитку когенерації в Україні}

На сьогодні основні положення щодо когенерації прописані в Законі України «Про комбіноване вироб- 


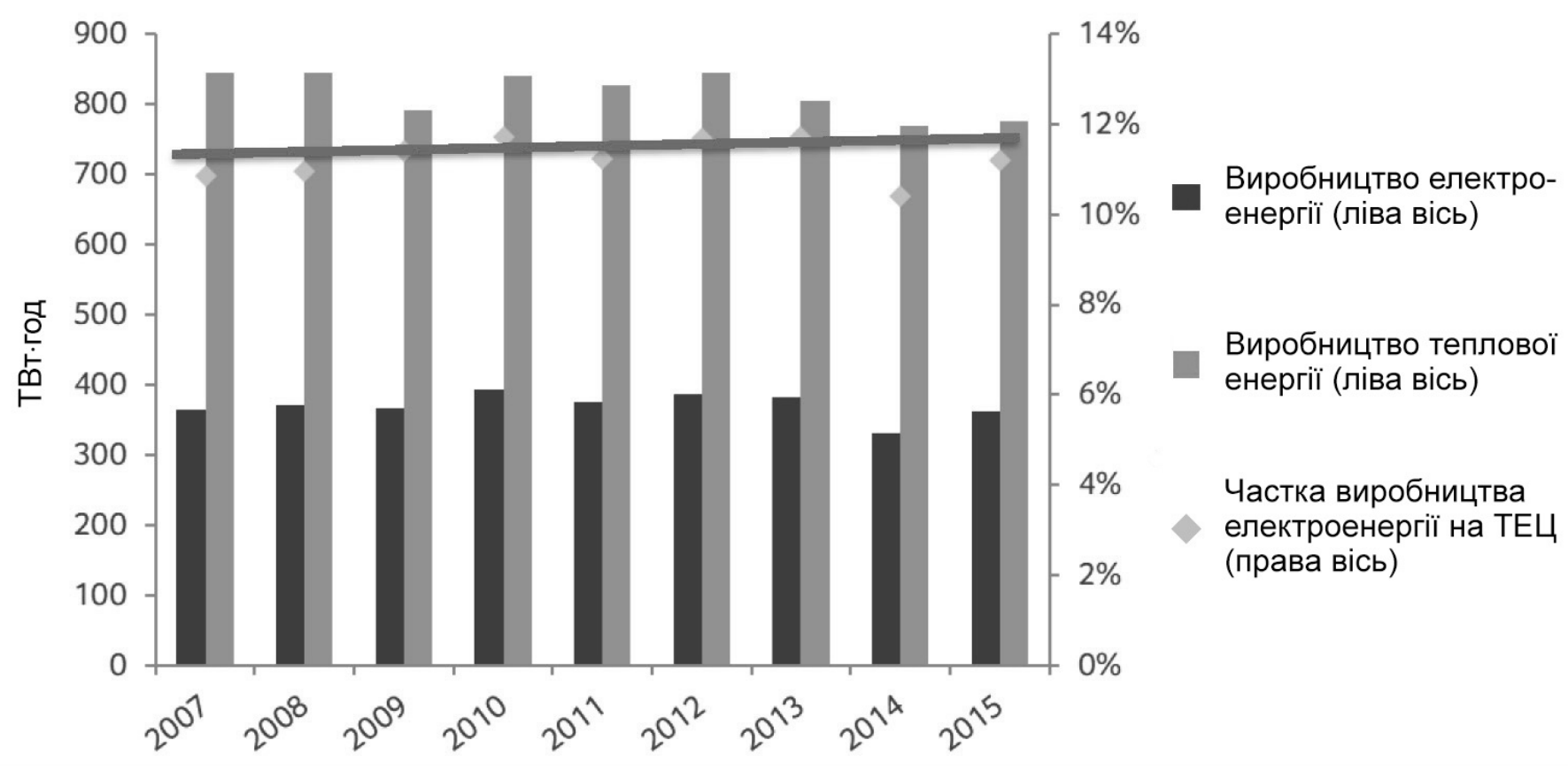

Рис. 2. Виробництво теплової і електричної енерхії та частка виробництва електроенерхії на ТЕЦ в Свросоюзі [2]

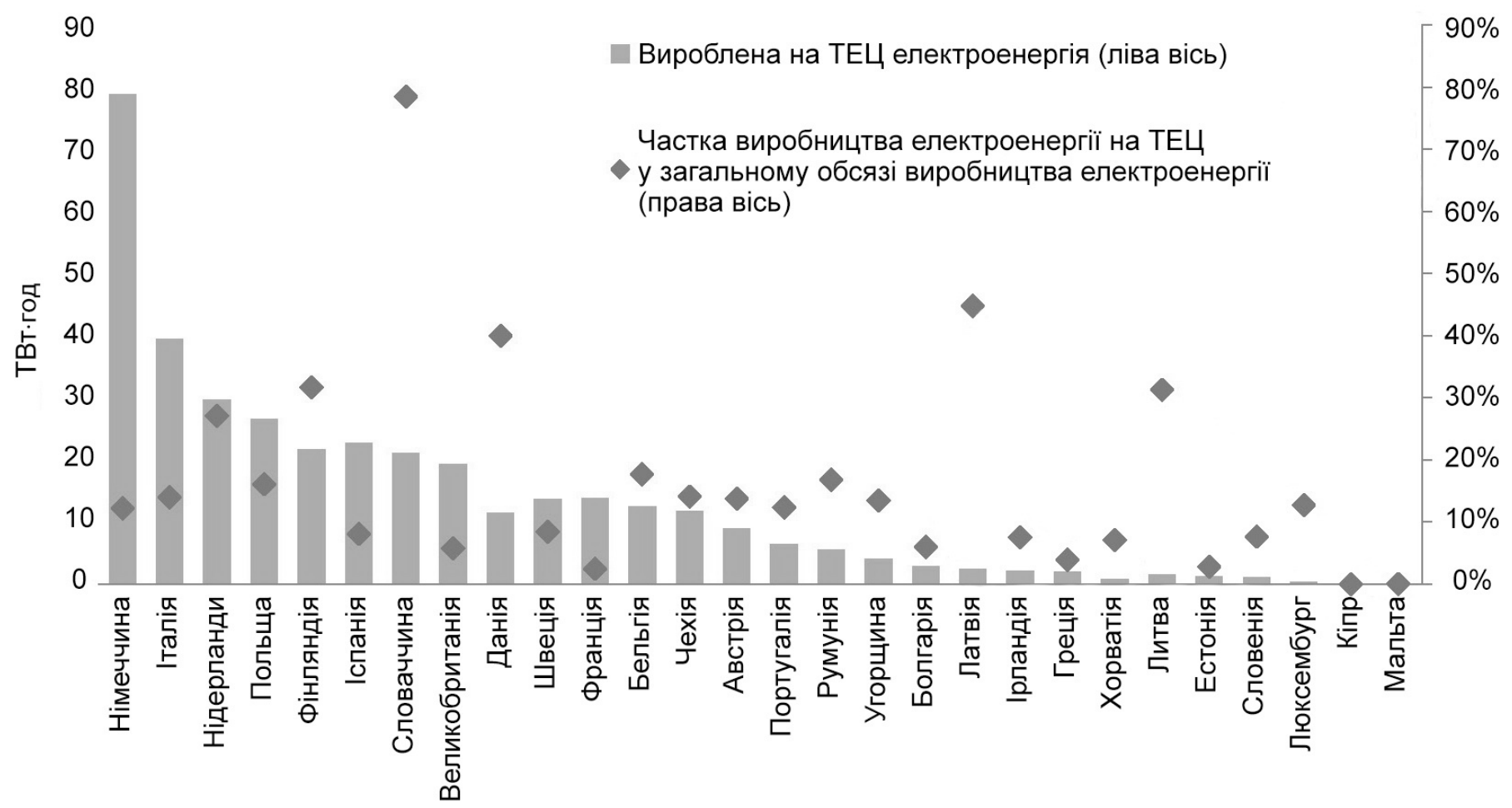

Рис. 3. Частка виробництва електроенергї̈ на ТЕЦ в загальному обсязі виробництва електроенергії в країнах $E C(2015$ р.) [2]. 
Табл. 2. Основні механізми підтримки когенерації в деяких країнах Європейського Союзу та світу (дані 2016 р.) [3-5]

\begin{tabular}{|c|c|}
\hline Країна & Інструменти стимулювання когенерації \\
\hline Австрія & Інвестиційні гранти. \\
\hline Чехія & Тарифні бонуси. Податкові пільги. \\
\hline Польща & $\begin{array}{l}\text { Система кольорових сертифікатів для підтримки високоефективної когенерації. } \\
\text { Інвестиційні гранти. }\end{array}$ \\
\hline Данія & $\begin{array}{l}\text { Цінові механізми («зелені» тарифи, 3-ставкові тарифи, тарифні бонуси). } \\
\text { Вимоги щодо підключення нових та існуючих будівель до системи районного опалення. }\end{array}$ \\
\hline Фінляндія & $\begin{array}{l}\text { Тарифні бонуси. Податкові пільги. Інвестиційні гранти. } \\
\text { Зменшення адміністративних бар’єрів після лібералізації ринку. } \\
\end{array}$ \\
\hline Бельгія (Фландрія) & Система сертифікатів. Податкові пільги. Інвестиційні гранти. \\
\hline Франція & $\begin{array}{l}\text { Цінові механізми («зелені» тарифи, тарифні бонуси). Податкові пільги. } \\
\text { Зменшення адміністративних бар'єрів (обов’язок придбання електроенергії, виробленої } \\
\text { в режимі когенерації). }\end{array}$ \\
\hline Німеччина & Цінові механізми («зелені» тарифи, тарифні бонуси). Податкові пільги. \\
\hline Греція & «Зелені» тарифи. \\
\hline Угорщина & $\begin{array}{l}\text { Пріоритетна подача електроенергії до мережі. Система гарантій походження } \\
\text { для електроенергії від високоефективних КГУ та для «зеленої» електроенергії. } \\
\text { Пільгові кредити для малих і середніх підприємств. }\end{array}$ \\
\hline Ірландія & «Зелені» тарифи. Податкові пільги. \\
\hline Італія & Система сертифікатів. Податкові пільги. \\
\hline Нідерланди & Податкові пільги. Інвестиційні гранти. \\
\hline Португалія & «Зелені» тарифи. \\
\hline Словаччина & Тарифні бонуси. \\
\hline Великобританія & «Зелені» тарифи. Податкові пільги. \\
\hline Іспанія & Тарифні бонуси. \\
\hline Японія & Державні субсидії і податкові пільги. \\
\hline Південна Корея & Державні субсидії і податкові пільги. \\
\hline США & На федеральному рівні прийнято Дорожню карту щодо стимулювання розвитку ТЕЦ. \\
\hline
\end{tabular}

ництво теплової та електричної енергії (когенерацію) та використання скидного енергопотенціалу» (№ 2509-IV від 05.04.2005, із змінами). Фактично, цей Закон має декларативний характер і не передбачає ніяких стимулів для розвитку когенерації в країні.

У 2017 році було прийнято Енергетичну стратегію України на період до 2035 року [6], згідно якої до пріоритетних напрямків відносяться (серед іншого):

- оптимізація джерел теплогенерації з фокусом на когенераційні потужності та максимізацію ККД;

- оптимізація використання когенерації на ТЕЦ для виробництва тепла та електроенергії;

- запровадження стимулюючого тарифу для підприємств теплопостачання та когенерації;

- підтримка реалізації проектів з когенерації на ТЕЦ і когенерації на біопаливі;

- підтримка будівництва високоефективної когенерації.
Для досягнення цілей Енергетичної стратегії КМУ було затверджено План заходів з реалізації етапу «Реформування енергетичного сектору (до 2020 року)» [7]. Одним 3 пунктів цього документу передбачено розроблення та подання КМУ проектів законодавчих актів щодо стимулювання впровадження високоефективних когенераційних установок (п. 72, головний виконавець Мінрегіон).

Аналогічне положення міститься у Плані заходів із впровадження Концепції реалізації державної політики у сфері теплопостачання до 2020 року [8]: забезпечити супроводження у Верховній Раді України проекту Закону України «Про комбіноване виробництво теплової та електричної енергії (когенерацію) та використання скидного енергопотенціалу щодо розвитку високоефективної когенерації» (п. 9, головний виконавець Мінрегіон).

Проект Закону України «Про внесення змін до За- 
кону України «Про комбіноване виробництво теплової та електричної енергії (когенерацію) та використання скидного енергопотенціалу» щодо розвитку високоефективної когенерації» був зареєстрований у Верховній Раді України у грудні 2017 року (№ 7465 від 28.12.2017) [9].

Проектом Закону уведено поняття високоефективної когенерації та високоефективної когенераційної установки, які відповідають європейській практиці. Запроваджено вимогу здійснювати аналіз витрат і вигід щодо оцінки потенціалу застосування високоефективної когенерації 3 метою планування економічно ефективного варіанту теплопостачання в населених пунктах. Цей аналіз виконується для населених пунктів, в яких передбачається істотне оновлення діючих теплогенеруючих об'єктів або будівництво нових потужностей теплової генерації, до початку проведення робіт з будівництва, реконструкції або технічного переоснащення в разі, коли планується будівництво нової установки тепловою потужністю понад $20 \mathrm{MBT}$ або істотне оновлення існуючої установки загальною тепловою потужністю понад 20 МВт. Фактично, вимога здійснювати аналіз витрат і вигід щодо оцінки потенціалу застосування високоефективної когенерації являє собою спробу імплементації в законодавство України відповідних положень Директиви 2012/27/СС «Про енергоефективність» [10].

Незважаючи на загальну позитивну оцінку даного законопроекту, треба зазначити, що він потребує доопрацювання, основна мета якого - забезпечити підтримку правильного напрямку розвитку високоефективної когенерації в Україні. Для цього обов'язково необхідно врахувати реально існуючу структуру використання різних видів палива для окремого виробництва теплової i електричної енергії. Наразі в Україні понад половини загального обсягу електроенергії виробляється на АЕС, $34 \%$ - на ТЕС (вугільних), 7,5\% - на ТЕЦ (більше 52\% яких використовують газ як основне паливо), $6 \%$ - на ГЕС. Більше 60\% теплової енергії відпускається котельними (з яких 62\% працюють на природному газі), 30\% відпускається ТЕЦ $[11,12]$. Таким чином, видно, що частка електроенергії, виробленої з природного газу, $\epsilon$ доволі обмеженою, тоді як теплової енергії, навпаки, дуже високою - близько 54\% загального обсягу тепла виробляється 3 газу, у тому числі $38 \%$ - газовими котельнями.

Проект Закону по суті підтримує впровадження газових ТЕЦ, що не є економічно обгрунтованим в умовах України, оскільки електроенергія від газової ТЕЦ суттєво дорожче електроенергії від АЕС і ГЕС. Так, наприклад, за даними НКРЕКП [13], на березень-травень 2018 р. тариф на відпуск електроенергії Миколаївською ТЕЦ (основне паливо - природний газ) становив 241,41 коп./кВт·год, Одеською ТЕЦ (основне паливо - природний газ) - 281,87 коп./кВт·год. При цьому тариф на відпуск електроенергії АЕС був 54,03 коп./кВт.год (січень-травень 2018 р.). Середній тариф на 2018 р. для ГЕС ПрАТ «Укргідроенерго» складає 28,14 коп./ кВТ·год без ПДВ, для ГЕС ДП «НАЕК «Енергоатом»114,93 коп./кВт.год без ПДВ. Приклади тарифів, встановлених для вугільних ТЕС, показують, що вони також нижче тарифів для газових ТЕЦ. Так, Миронівській ТЕС встановлено тариф на відпуск електроенергії 235,68 коп./кВт·год без ПДВ (з 01.01.2018) [14]. Середня ціна продажу до оптового ринку електроенергії генеруючих компаній ТЕС у липні 2018 р. склала 176,48 коп./ кВт·год, АЕС - 54,63 коп./кВт·год, ГЕС (крім ГЕС, що працюють за «зеленим» тарифом) - 109,48 коп./кВт·год, ТЕЦ - 215,85 коп./кВт·год [15].

Вважаємо за необхідне розвивати когенерацію на місцевих видах палива. Для України місцевими паливами $\epsilon$ вугілля і біомаса, з яких остання має переваги 3 точки зору екологічних показників (щодо викидів сірки, оксидів азоту, парникових газів) і наявності достатнього місцевого ресурсного потенціалу. Теплова енергія від ТЕЦ на біомасі дешевша за теплову енергію з газу, а впровадження ТЕЦ на біомасі сприяє скороченню обсягів споживання природного газу і робить внесок в економічний розвиток регіонів України. Будівництво ТЕЦ на біомасі має певні обмеження, такі як щільність забудови населеного пункту, проблеми логістики, але у випадках відсутності цих обмежень і при позитивних результатах техніко-економічного обгрунтування вважаємо реалізацію проектів даного типу доцільною.

Хоча когенерація $є$ більш ефективним способом виробництва теплової і електричної енергії у порівнянні 3 роздільним виробництвом, при оцінці потенціалу ii застосування мають використовуватися правильні підходи. Вважаємо, що при проведенні аналізу витрат і вигід (тобто фактично ТЕО) щодо оцінки потенціалу застосування високоефективної когенерації така оцінка має виконуватися для різних видів палива, у тому числі біопалива, а не тільки для природного газу.

У поточній редакції законопроекту відсутні механізми стимулювання (через преференції) або регулювання (через адміністративні заходи) розвитку виробництва теплової і електричної енергії високоефективними КГУ в Україні. Як вже зазначалося, на сьогодні в Україні на ТЕЦ виробляється близько 7,5\% загального обсягу електроенергії, тоді як інших в країнах Свропи 3 високорозвиненою системою централізованого теплопостачання цей показник набагато вище: Словаччина $-80 \%$, Латвія - 45\%, Данія - 40\%, Фінляндія $30 \%$, Литва - 30\%. В країнах ЄС застосовуються різні механізми стимулювання розвитку когенераціїних технологій, існують цілі і плани щодо подальшого нарощування потужності ТЕЦ. Вивчення та аналіз досвіду ЄC 3 підтримки когенерації може бути корисним для 
України з точки зору вибору найбільш оптимального інструменту стимулювання.

Пропозиції щодо покращення змісту поточної версії проекту Закону № 7465 в загальному вигляді можна сформулювати наступним чином:

- додати визначення терміну «ефективне централізоване теплопостачання і охолодження» у відповідності до Директиви 2012/27/СС «Про енергоефективність»;

- замінити термін «аналіз витрат і вигід» на «попереднє техніко-економічне обгрунтування» або інший термін, прийнятий в нормативно-правових актах України;

- увести зобов'язання та/або засоби сприяння впровадженню когенераційної установки у разі позитивного результату виконання аналізу витрат і вигід (попереднього ТЕО) щодо оцінки потенціалу застосування високоефективної когенерації.

- увести систему стимулювання та/або адміністративного зобов'язання для розвитку високоефективної когенерації в Україні.

\section{Висновки}

Україна має добрі передумови для розвитку когенераційних технологій, що сприятиме скороченню споживання паливно-енергетичних ресурсів за рахунок більш ефективного виробництва теплової i електричної енергії у порівнянні з роздільним виробництвом. Вважаємо за необхідне розвивати когенерацію на біопаливі. Теплова енергія від ТЕЦ на біопаливі дешевша за теплову енергію з газу, а впровадження таких ТЕЦ призводить до скорочення обсягів споживання природного газу і робить внесок в економічний розвиток регіонів України. Вважаємо за доцільне доопрацювання проекту Закону України «Про внесення змін до Закону України «Про комбіноване виробництво теплової та електричної енергії (когенерацію) та використання скидного енергопотенціалу» щодо розвитку високоефективної когенерації» (№ 7465 від 28.12.2017) у відповідності до розроблених рекомендацій.

\section{ЛІТЕРАТУРА}

1. Національний план дій з енергоефективності на період до 2020 року. Схвалено Розпорядженням КМУ № 1228-р від 25.11.2015 http://zakon2.rada.gov.ua/laws/ show/n0001824-15/paran2\#n2

2. Alexandra Tudoroiu-Lacavice. Cogeneration becoming a cornerstone of our future energy system. Presentation at the seminar "From big to small: various power and heat supplying concepts with CHP", Hannover, 24.04.2018

http://files.messe.de/abstracts/85460_uni Tudoroiu.pdf

3. Alexandra Tudoroiu-Lacavice, Stane Merse. COGEN Europe national snapshot survey. Presentation as of 22.03.2016

http://www.cogeneurope.eu/medialibrary/2016/03/31/ eaf93a61/2016_03_22\%20COGEN\%20Europe_ Snapshot\%20Survey.pdf
4. Зарубіжний досвід розвитку систем централізованого та автономного тепло- та електропостачання. ДП «НЕК Укренерго», 2016

https://ua.energy/wp-content/uploads/2018/01/5.TSentralizovane-ta-avtonomne-teplozabezpechennya.pdf 2014

5. Cogeneration Roadmap, Hungary. D5.1, CODE2,

http://www.code2-project.eu/wp-content/uploads/201412-CODE2-Roadmap-Hungary-final.pdf

6. Енергетична стратегія України на період до 2035 року. Схвалено Розпорядженням КМУ № 605-р від 18.08.2017 https://www.kmu.gov.ua/ua/npas/250250456

7. План заходів з реалізації етапу "Реформування енергетичного сектору (до 2020 року)" Енергетичної стратегії України на період до 2035 року "Безпека, енергоефективність, конкурентоспроможність". Затверджено Розпорядженням КМУ № 497-р від 06.06.2018

http://zakon0.rada.gov.ua/laws/show/497-2018$\% \mathrm{D} 1 \% 80$

8. План заходів із впровадження Концепції реалізації державної політики у сфері теплопостачання до 2020 року. Затверджено Розпорядженням КМУ № 307-р від 10.05.2018

http://zakon0.rada.gov.ua/laws/show/307-2018$\% \mathrm{D} 1 \% 80$

9. Проект Закону України «Про внесення змін до Закону України «Про комбіноване виробництво теплової та електричної енергії (когенерацію) та використання скидного енергопотенціалу» щодо розвитку високоефективної когенерації» (№ 7465 від 28.12.2017)

h t t p : / / w 1.c 1.rada.gov.ua/p1 s/ z w e b 2 / webproc4 1?pf3511 $=63282$

10. Directive 2012/27/EU of 25 October 2012 on energy efficiency

https://eur-lex.europa.eu/legal-content/EN/TXT/PDF/?u $\mathrm{ri}=\mathrm{CELEX}: 32012 \mathrm{~L} 0027 \&$ from $=\mathrm{EN}$

11. Статистичний бюлетень «Постачання та використання енергії» за 2016 рік. Державна служба статистики України, 2017.

12. Енергетичний баланс України за 2016 рік. Експрес-випуск Державної служби статистики України № 506/0/08.4вн-17 від 20.12.2017.

13. Тарифи на відпуск електричної енергії. НКРЕКП, 2018

http://www.nerc.gov.ua/data/filearch/elektro/taryfy_na vidpusk-elektro.pdf

14. Постанова НКРЕКП Про встановлення тарифів на відпуск електричної енергії та виробництво теплової енергії ПАТ «ДТЕК Донецькобленерго» ВП «Миронівська ТЕС» (№ 1499 від 28.12.2017 із змінами)

http://www.nerc.gov.ua/index.php?id=30156

15. Динаміка цін продажу електроенергії в Оптовий ринок електроенергії виробниками. ДП «Енергоринок», 2018 http://www.er.gov.ua/doc.php?f=3995 


\section{PROBLEMS AND PROSPECTS FOR THE DEVELOPMENT OF COGENERATION IN UKRAINE}

\section{Geletukha G.G., Zheliezna T.A., Bashtovyi A.I.}

Institute of Engineering Thermophysics of the National Academy of Sciences of Ukraine, Zhelyabova str., $2 a$, Kyiv, 03057, Ukraine

\section{https:doi.org/10.31472/ttpe.1.2019.8}

The purpose of the work is to determine the preconditions and perspective lines for the development of high-efficiency cogeneration in Ukraine. The tasks of the work consist in a review of European experience in this area, an analysis of the relevant Ukrainian legislation, and the development of recommendations for its improvement. Methods of research include the study of literary, statistical and other data, analysis of regulatory acts. The results of the work show that Ukraine has good preconditions for the development of cogeneration technologies, which will reduce the consumption of fuel and energy resources due to more efficient production of heat and power compared to their separate production. The experience of EU countries on the development of cogeneration is considered, the existing mechanisms of support of this sector are analysed. The necessity to develop cogeneration on local fuels in Ukraine is substantiated. For Ukraine, local fuels are coal and biomass, of which the latter has advantages in terms of environmental performance (emissions of sulphur, nitrogen oxides, and greenhouse gases) and the availability of sufficient potential of local resources. Heat produced by a biomass CHP plant is cheaper than heat from gas, and the introduction of biomass CHP plants results in the reduction of natural gas consumption and contributes to the economic development of Ukraine's regions. Construction of a biomass CHP plant has certain limitations, such as the density of settlement development, the problems of logistics, but in the absence of these restrictions, and with the positive results of the feasibility study, the implementation of projects of this type is expedient. The legal basis of cogeneration development in Ukraine is analysed, the need for its improvement is shown. Recommendations for the improvement of an existing draft law on the development of high efficiency cogeneration in Ukraine have been developed.

References 15, tables 2, figures 3.

Keywords: cogeneration, high-efficiency cogeneration, combined heat and power production, heat power plant, heat, power.

1. Natsionalnyi plan dii $\mathrm{z}$ enerhoefektyvnosti na period do 2020 roku. Skhvaleno Rozporiadzhenniam KMU № 1228-r vid 25.11.2015 [National action plan on energy efficiency up to 2020. Approved by the Cabinet of Ministers of Ukraine Executive Order No. 1228-p of 25 November
2015] http://zakon2.rada.gov.ua/laws/show/n0001824-15/ paran2\#n2 (Ukr.)

2. Alexandra Tudoroiu-Lacavice. Cogeneration becoming a cornerstone of our future energy system. Presentation at the seminar "From big to small: various power and heat supplying concepts with CHP", Hannover, 24.04.2018

http://files.messe.de/abstracts/85460 uni Tudoroiu.pdf

3. Alexandra Tudoroiu-Lacavice, Stane Merse. COGEN Europe national snapshot survey. Presentation as of 22.03.2016

http://www.cogeneurope.eu/medialibrary/2016/03/31/ eaf93a61/2016_03_22\%20COGEN\%20Europe_ Snapshot\%20Survey.pdf

4. Zarubizhnyi dosvid rozvytku system tsentralizovanoho ta avtonomnoho teplo- ta elektropostachannia. DP "NEK Ukrenerho" [Foreign experience in the development of centralized and autonomous heat and power supply systems. SE "NEC Ukrenergo"], 2016 (Ukr.)

https://ua.energy/wp-content/uploads/2018/01/5.TSentralizovane-ta-avtonomne-teplozabezpechennya.pdf 2014

5. Cogeneration Roadmap, Hungary. D5.1, CODE2,

http://www.code2-project.eu/wp-content/uploads/201412-CODE2-Roadmap-Hungary-final.pdf

6. Enerhetychna stratehiia Ukrainy na period do 2035 roku. Skhvaleno Rozporiadzhenniam KMU № 605-r vid 18.08.2017 [Energy Strategy of Ukraine until 2035. Approved by the Cabinet of Ministers of Ukraine Executive Order No. 605-r of 18.08.2017] (Ukr.) https://www.kmu. gov.ua/ua/npas/250250456

7. Plan zakhodiv $\mathrm{z}$ realizatsii etapu "Reformuvannia enerhetychnoho sektoru (do 2020 roku)" Enerhetychnoi stratehii Ukrainy na period do 2035 roku "Bezpeka, enerhoefektyvnist, konkurentospromozhnist". Zatverdzheno Rozporiadzhenniam KMU № 497-r vid 06.06.2018 [Action Plan for the implementation of the "Energy Sector Reform (up to 2020)" of Energy Strategy of Ukraine until 2035 "Safety, energy efficiency, competitiveness". Approved by the Cabinet of Ministers of Ukraine Executive Order No. 495-r of 06.06.2018] (Ukr.)

http://zakon0.rada.gov.ua/laws/show/497-2018$\% \mathrm{D} 1 \% 80$

8. Plan zakhodiv iz vprovadzhennia Kontseptsii realizatsii derzhavnoi polityky u sferi teplopostachannia do 2020 roku. Zatverdzheno Rozporiadzhenniam KMU № 307-r vid 10.05.2018 [Action Plan for the realization of the Concept of the state policy implementation in the field of heat supply till 2020. Approved by Cabinet of Ministers of Ukraine Executive Order No. 307-p of 10.05.2018] (Ukr.)

http://zakon0.rada.gov.ua/laws/show/307-2018$\% \mathrm{D} 1 \% 80$

9. Proekt Zakonu Ukrainy "Pro vnesennia zmin do Zakonu Ukrainy "Pro kombinovane vyrobnytstvo teplovoi ta elektrychnoi enerhii (koheneratsiiu) ta vykorystannia 
skydnoho enerhopotentsialu» shchodo rozvytku vysokoefektyvnoi koheneratsii” (№ 7465 vid 28.12.2017) [Draft Law of Ukraine "On Amendments to the Law of Ukraine "On Combined Heat and Power Production (Cogeneration) and Utilization of Waste Energy Potential" for the Development of High-Efficiency Cogeneration" (No. 7465 of 28.12.2017)] (Ukr.)

h t t p : //w 1.c 1.rada.gov.ua/p 1 s/zweb $2 /$ webproc4_1?pf3511=63282

10. Directive 2012/27/EU of 25 October 2012 on energy efficiency

https://eur-lex.europa.eu/legal-content/EN/TXT/PDF/?u $\mathrm{ri}=\mathrm{CELEX}: 32012 \mathrm{~L} 0027 \&$ from $=\mathrm{EN}$

11. Statystychnyi biuleten «Postachannia ta vykorystannia enerhii» za 2016 rik. Derzhavna sluzhba statystyky Ukrainy, 2017 [Statistical bulletin "Supply and use of energy" for 2016. State Statistics Service of Ukraine, 2017] (Ukr.)

12. Enerhetychnyi balans Ukrainy za 2016 rik. Ekspres-vypusk Derzhavnoi sluzhby statystyky Ukrainy № 506/0/08.4vn-17 vid 20.12.2017 [Energy balance of Ukraine for 2016. Express-issue by State Statistics Service of Ukraine No. 506/0/08.4vn-17 of 20.12.2017] (Ukr.)
13. Taryfy $n a$ vidpusk elektrychnoi enerhii. NKREKP, 2018 [Electricity tariffs. National Energy and Utilities Regulatory Commission, 2018] (Ukr.)

http://www.nerc.gov.ua/data/filearch/elektro/taryfy_na vidpusk-elektro.pdf

14. Postanova NKREKP "Pro vstanovlennia taryfiv na vidpusk elektrychnoi enerhii ta vyrobnytstvo teplovoi enerhii PAT “DTEK Donetskoblenerho" VP “Myronivska TES” (№ 1499 vid 28.12.2017 iz zminamy) [The Resolution of the National Energy and Utilities Regulatory Commission "On establishing tariffs for electricity supply and heat production of PJSC "DTEK Donetskoblenerho" SD "Myronivska TPP" (No. 1499 of 28.12.2017 as amended)] (Ukr.) http://www. nerc.gov.ua/index.php?id $=30156$

15. Dynamika tsin prodazhu elektroenerhii v Optovyi rynok elektroenerhii vyrobnykamy. DP «Enerhorynok», 2018 [The dynamics of electricity sales prices in the Wholesale Electricity Market by producers. SE "Energorynok", 2018] (Ukr.) http://www.er.gov.ua/doc.php?f=3995

Отримано 09.11.2018 Received 09.11.2018 